\title{
A SURVEY OF ENVIRONMENTAL PROBLEMS IN EASTERN EUROPE
}

\author{
ALBERT E. STEENGE
}

\begin{abstract}
This paper deals with the increasing interaction of economic and environmental issues in Eastern Europe. The paper starts with a discussion of environmental problems in these formerly centrally planned economies. The grave environmental problems these countries face are surveyed and an explanation is provided in terms of the nature of the communist system. While a solution must be sought in an international cooperation context, involving the developed West European countries, many emerging international cooperation schemes inspired by environmental economic theory are no longer effective in the light of the disastrous loss of competitiveness of East European industries. New initiatives on the part of West European countries seem to be called for.
\end{abstract}

\section{INTRODUCTION}

Today, environmental problems in Eastern Europe are regularly covered not only in the popular press, but also in scientific publications. These accounts often originate in the activities of local pressure groups in Eastern Europe. Especially after the Chernobyl disaster (April 1986), which functioned as a catalyst, Western public interest in these issues has increased spectacularly. After the collapse of the communist regimes, a great deal of information has also flowed from the official channels and is only now beginning to be processed. Formidable damage to public health, agriculture, and ecosystems has been reported and linked to severe environmental problems. A rough indication of the situation in six formerly centrally planned countries is given in Table 1. (Due to a lack of reliable data, the Soviet Union is not included.)

Zylicz (1990) interprets the picture resulting from Table 1 in terms of general system inefficiency and policy failure in the former Council for Mutual Economic Assistance (CMEA) countries. We will discuss these aspects in Section 3.

Despite the abundance of information becoming available, it is difficult to assemble a coherent description, let alone to carry out systematic analyses. Consequently, it is also difficult to design policy objectives and instruments. Can the traditional instruments of environmental economics be useful or are they insensitive to the problems of Eastern Europe? Are they geared only to 'Western' or 'capitalist' economies? Can they be effective in a situation of disorder involving massive unemployment or mass migration?

Address: Faculty of Public Administration, University of Twente, POB 217, 7500 AE Enschede, The Netherlands. 
TABlE 1. Centrally Planned Economies and the Environment in Europe, 1980s: ${ }^{1}$ Percentage of European Totals (excl. USSR)

\begin{tabular}{lc}
\hline & $C M E A-6^{2}$ \\
\hline 1 Population & 23 \\
2 Area & 20 \\
3 National product & 12 \\
4 Energy consumption (calories) & 27 \\
5 Energy consumption (oil quality equivalent units) & 21 \\
6 Emission of $\mathrm{SO}_{2}$ & 38 \\
7 Emission of $\mathrm{NO}_{x} \mathrm{SO}_{2}$ and $\mathrm{NO}_{x}$ & 21 \\
8 Joint emissions of $\mathrm{SO}_{2}$ & 33 \\
9 Emissions of particulates & 53 \\
\hline
\end{tabular}

\footnotetext{
1 Due to a lack of reliable statistical data on Romania and on a number of smaller countries, the CMEA's share will be somewhat underestimated.

${ }^{2}$ GDR, Poland, Czechoslovakia, Hungary, Bulgaria, and Romania. Source: Zylicz (1990).
}

In this paper we survey the present situation and evaluate some options. We examine approaches to environmental relief that were being considered for Eastern Europe before the revolutions of 1989 and 1990 when a network of international cooperation was gradually developing.

We show that the revolutions of 1989 and 1990 in Eastern Europe disrupted this emerging network. Now all problems related to environmental economicseconomic growth and development, the sustainability issue, cost-benefit evaluations - need to be considered simultaneously, and we are wholly unprepared for such an undertaking. Yet all these issues need to be linked to the reform programs being formulated. This is a tremendous and new problem since a generally accepted theory of reconstruction does not yet exist. One reason for this is that economists in general were almost totally unprepared for the systemic changes of 1989 and 1990 . The present situation has already been described as 'reforms without theory' (Hare, 1990; Kaser, 1990).

We shall begin by surveying the environmental problems. The next section deals with its systemic origins and causes; this is followed by a review of theoretical and actual outcomes and present European Community (EC) policy. Finally, some conclusions are offered.

\section{MAIN FORMS OF ENVIRONMENTAL POLLUTION}

All types of pollution found in the West European countries are also present in Eastern Europe, but the intensity of pollution in the latter is far more serious in nearly all cases. In this section we shall give a brief survey of the main categories of pollution, following the conventional distinctions between air, water, and soil pollution. (Other factors such as noise pollution, congestion factors, and solid waste management appear to be somewhat less critical and more or less comparable to Western experience.) Important sources are Cesar (1990), French (1990), and Wilczynski (1990). A brief survey of the current state of affairs in the Soviet Union is given in IMF et al. (1991). 


\subsection{Air Pollution}

The type of air pollution in Eastern Europe reflects the kind of energy resources that have been locally available. The drive for self-sufficiency and the general lack of hard currency strongly stimulated the exploitation of the large deposits of brown coal or lignite in the GDR, Poland, and Czechoslovakia. The choices made are reflected in a pattern of energy consumption characteristic of much of Eastern Europe (see Table 2).

Sulphur emissions, especially caused by combustion in highly inefficient coal power plants for energy production, are probably the largest airborne contributor to acid rain. In Eastern Europe they are notoriously high. Inefficiency in the generation of electricity is due mainly to the combustion of indigenous supplies of lignite, soft or brown coal with an extremely high sulphur content (from 2-2.5\% up to $5 \%$ or even more in the lowest-quality types of fuel) and a low calorific value [often less than $50 \%$ of the major types of hard coal (French, 1990)]. Table 3 gives an indication of the amounts of $\mathrm{SO}_{2}, \mathrm{NO}_{x}$, and $\mathrm{CO}_{2}$ being generated.

Variations in the table reflect local differences. For example, $80 \%$ of Poland's energy is supplied by coal. Although a less polluting type of hard coal is often used here, these fuels possess other undesirable characteristics, such as a high ash content, resulting in high concentrations of ash or dust particles. This explains why particulates (soot) and nitrogen oxides $\left(\mathrm{NO}_{x}\right)$ are the second worst airborne pollutants. On the local level, industrial and domestic installations such as those used for the production of fertilizers, asbestos, and cement, and in metallurgy, are a separate source of air pollution. In the big cities extreme pollution from vehicles $\left(\mathrm{NO}_{x}, \mathrm{CO}\right.$, lead, and soot) is a major nuisance. The sulphur concentration in the centre of Prague is reportedly twice as high as that in Rio de Janeiro, Seoul, or Beijing (French, 1990). The entries in Table 3 are generally in line with the data provided by other sources, such as the Baseline Scenario estimates by Duchin et al. (1991). A major difference is the Baseline Scenario estimate of $\mathrm{SO}_{2}$ emissions, which is given as 24.1 million tons in 1990 , i.e. $50 \%$ more than the entry in Table 3 (for 1985/86). A possible explanation might be found in the average sulphur content on which the estimates are based; see further Duchin et al. (1991, ch. 2).

\subsection{Water Pollution}

The main sources of direct river and lake pollution in Eastern Europe traditionally are the large-scale production of energy, inefficient agricultural sectors (reflected in an overuse of fertilizers and pesticides), and untreated or inadequately treated industrial discharges and effluents rich in heavy metals and toxic chemicals. Large quantities of waste water from coal mining and other mineral extraction and untreated domestic sewage are another huge category. The former GDR in addition has a substantial radioactive waste problem as a result of careless uranium mining.

Consequently, drinking water supplies throughout Eastern Europe are heavily contaminated. In particular, vast reaches of the Vistula river in Poland are 
318 A. E. STEENGE

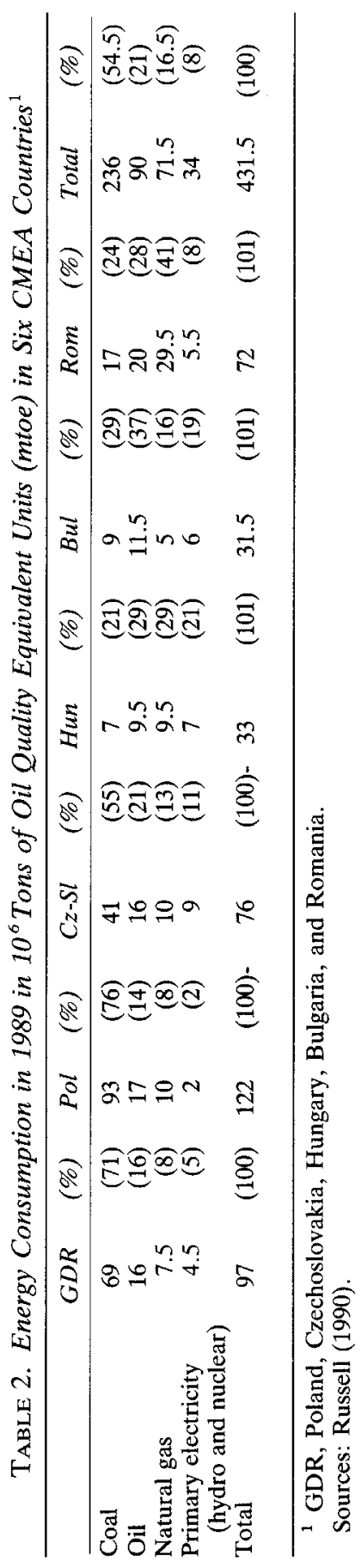


TABle 3. Gaseous Emissions in Eastern Europe ${ }^{1}$

\begin{tabular}{llllllll}
\hline & $G D R$ & Pol & $C z-S l$ & Hun & Bul & Rom & Total \\
\hline $\begin{array}{l}\mathrm{SO}_{2} \text { emissions in 1985/86 } \\
\quad\left(10^{6} \text { tons/year) }\right.\end{array}$ & 5.0 & 4.3 & 3.4 & 1.4 & 1.1 & 0.2 & 15.4 \\
$\mathrm{NO}_{x}$ emissions in 1988 & 0.995 & 1.550 & 0.950 & 0.259 & 0.150 & 0.390 & 4.254 \\
$\begin{array}{l}\left(10^{6} \text { tons year) }\right. \\
\mathrm{CO}_{2} \text { emissions estimated from 1989 } \\
\text { fossil fuel utilization }\left(10^{9} \text { metric }\right. \\
\text { tons of carbon/year) }\end{array}$ & 0.088 & 0.116 & 0.060 & 0.020 & 0.023 & 0.052 & 0.359 \\
\hline
\end{tabular}

${ }^{1}$ GDR, Poland, Czechoslovakia, Hungary, Bulgaria, and Romania.

Source: Russell (1990). These statistics are based on material from many sources (both West and East European).

deemed unfit even for industrial use without further treatment. Indirect pollution is caused by the acidification of lakes and rivers.

Water quality problems are not only domestic but also transboundary (in the case of the Elbe, Moldau, and Vistula rivers). About 30\% of all rivers in this region are reported to be organically dead. Internationally accepted water quality standards are regularly exceeded by a factor of more than 100 (French, 1990).

\subsection{Toxic Wastes and Soil Pollution}

Soil pollution refers to contamination of the soil and ground water by pesticides, heavy metals, or acid deposition. The destruction of the top layers of soil due to open pit mining of brown coal and lignite also belongs in this category. This extraction method causes widespread destruction of arable and buildable land and ecosystems. Moreover, we see a lot of soil erosion due to mismanagement or malpractice. The widespread use of fertilizers, open cast mining, and dumping of toxic waste has led to soil contamination and the poisoning of domestic food supplies, as well as having adverse effects on livestock. For example, $60 \%$ of food products in the Krakow area in Southern Poland is said to be unfit for human consumption because of the heavy metal contamination (Cesar, 1990).

\subsection{The Aftermath of Chernobyl}

The consequences of the Chernobyl catastrophe form a separate category of environmental pollution due to mismanagement accompanied by efforts to maintain secrecy and withhold information on the accident. Realistic assessment of the damage is only beginning. Extremely disturbing data are provided in Wolfson (1990) in the form of a preview of a forthcoming report by $L$. Kovaleskaya on this matter. It is revealed, for example, that since 1986, $600,000-800,000$ people have been involved in the clean-up process, almost all of them ill-prepared and badly protected for the job.

The latest reports suggest that about four million people are living in territories where fallout makes normal life impossible. In these areas, for example, children are not allowed to play outside, except in special decontaminated zones. Crops grown on local farms are regularly destroyed. Byelorussia, which was subjected to $70 \%$ of the total fallout, lost over $20 \%$ of its arable land; more than half of its 
territory was contaminated to some degree (Rich, 1991). Other risks of exposure, including problems concerning the sarcophagus in which the exploded reactor was buried, are discussed by Bojcun (1991). Evidence on the ecological situation is given in Spetter (1990).

\subsection{Consequences}

Longitudinal empirical work, based on time series of sufficient length and quality, has clearly not yet been carried out. Consequently it is difficult to evaluate the effects of pollution in Eastern Europe. Nevertheless, a number of interesting studies of a comparative nature have been published recently, including those collected by Wnuk-Lipinski and Illsley (1990). These articles focus on the discrepancies in health between different subsets of the population, reflecting differential access to health care systems and resulting in unequal incidence of diseases, disabilities, and deaths. Major inequalities appeared to be due to an informal system of social and economic privilege. On a deeper level, the overall inadequacy of the health care system reflects the systemic priority given to material production at the expense of services of a public nature.

Other studies have established links between mental retardation in Eastern Europe and the heavy metal pollution of food chains and drinking water. In fact, populations have occasionally been removed from areas where pollution posed a noticeable risk. Infant mortality in Czechoslovakia is twice that of Sweden. The risk of cancer for East Europeans is about 5-25 times that of Americans (Cesar, 1990). Incidences of lung disease and lead poisoning are unusually high. Alcoholism and its effects are a recurring theme, often attributed to the deteriorating living conditions; in this sense little has changed since Vladimir Treml's study of alcoholism in the USSR (Treml, 1982).

Direct effects on the economy are clearly visible: decreased yields and reduced quality of agricultural crops, damaged forests (for a recent survey see Mazurski, 1990), accelerated corrosion of machines and buildings, and a general deterioration of health resulting in a decline in labour productivity. Direct pollutionrelated costs are assessed as being 5-15\% of the GNP annually (French, 1988, 1990; Famielec and Gorka, 1991). The indirect and long-term pollution-related costs, of course, are far more difficult to estimate and will take a long time to sort out.

\section{SYSTEMIC CAUSES OF ENVIRONMENTAL DEGRADATION}

The Stalinist programs which were imposed on the East European countries after World War II led to a break in long-term growth and development patterns. Commitment to the 'plan' required suppressing 'disturbing' market effects. One consequence was isolation from the world economic system, i.e. the imposition of a regime of economic self-reliance. This in turn meant that good relations could be developed only with other centrally planned countries. The Council for Mutual Economic Assistance (CMEA) was the main vehicle for the structuring of foreign trade among these countries. Trade with the rest of the world remained extremely 
low, typically amounting to only a small percentage of the total trade. Characteristics of these planned economies are discussed below.

\subsection{Concentration on Heavy Industry}

The emphasis on rapid industrialization at any cost, particularly in the basic iron, steel, and chemical sectors, was implemented by state ownership of the means of production and a price system featuring cheap factors of production to boost productivity. The prices of energy and resources were kept artifically low. Also, the environment, seen solely as a factor of production, was kept at a zero price.

Because of their specific input proportions, the concentration on heavy industries itself is a source of increased consumption of energy and resources and increased emissions into air, water, and soil. This emphasis on heavy industry continued during the late sixties and the seventies, largely dependent on substantial Western loans. This led eventually to over-industrialization, also often referred to as 'production for the sake of production'. [For a discussion of general aspects of Soviet-type industry, see further Berliner (1988).]

\subsection{Low Energy Efficiency}

Isolation from the world economy, the policy of cheap energy, and the general lack of incentives under the central planning system resulted in inefficient production. The accounting prices charged to producers in primary sectors such as mineral extraction and wood felling were set far too low. These prices were effectively fixed many years before and hardly reflected actual opportunity costs (i.e. the rate of return on alternative uses). No prices were charged for a number of natural resources, such as coal, oil, and gas reserves, water power, agricultural land, and use of water for irrigation. Consequently, financial funds in mining and the basic industries were too scarce to enable enterprises to finance investments in resource-saving systems. (Moreover, surpluses were appropriated by the state.) The consequence was an overall inefficiency in the use of (natural) resources. Budget-maximizing behaviour on the managerial side favoured procuring even more inputs than were actually needed (see Wilczynski, 1990).

Conservation is an impossibility under such circumstances. Poland provides a typical example. Despite considerable efforts, efficiency gains in terms of energy inputs are far lower than the Western gains in response to the oil crises; energy intensity (per unit of GDP) in Poland is still double that of the United States. In the Polish case this state of affairs is mainly because raw materials and heavy processing industries still dominate the country's industrial landscape. Progress in energy efficieny in these sectors has been very slow, averaging only $1.3 \%$ in the 1980-1985 period and virtually nothing since then (Chandler, 1990). The consequences are predictable. The coal sector is in reconstruction, and the supply of petrol is unreliable so an increase in Soviet gas supplies from $40 \mathrm{Bcm}$ in $1986-1990$ to $51 \mathrm{Bcm}$ in $1991-1995$ is seen as unavoidable. However, this will have to be purchased with hard currency now. Atomic energy would be another option, but the construction of nuclear facilities is stalled at present. Thus, Polish dependence on hard coal may increase because of rising energy prices, so that 
$\mathrm{SO}_{2}$ emissions may be expected to remain high. The dependence on inferior fuel types actually increased during the seventies, when the oil shocks led to the substitution of imported oil and gas by domestically produced coal. Poland now relies for about $80 \%$ of its needs on this kind of coal, which is three times more than the Netherlands, Spain, or the FRG (Chandler, 1990; Energy Economist, 1990).

\subsection{Systemic Explanation}

The above analysis does not fully explain why so little has been done to halt the deterioration of the environment. The available literature mainly discusses conditions at the plant or sector level and ignores the situation at higher organizational levels.

The root of the problem is not the absence of environmental legislation. Although there were almost no environmental laws during the early years of central planning, over the years an impressive body of laws protecting the environment has been developed in a number of countries. Now a consistent series of laws exists not only on the territory of the former GDR, but also in Poland, Hungary, and Rumania, while such laws are being rapidly developed in Czechoslovakia and Bulgaria. Legal and economic instruments include quality standards, impact and cost-benefit statements, sanctions, fees, and charges. 'The polluter pays' principle is generally adopted as the guiding principle for cost allocation.

The dismal state of the environment, however, is proof that these laws are often violated and have little impact in reality. Enterprises in a centrally planned system cannot aim at environmentally optimal outcomes as they are constrained to place priority on acquiring the necessary inputs for their main product. Cost reduction in the Western sense is not a systemic goal (as can be inferred from the central role played by Kornai-type soft-budget restrictions). This means that enterprises, if pressed, will prefer to pay the fine provided they are not 'too high'. If they are too high, the system will not work at all. This is exactly what we find: with a few exceptions, the share of charges does not exceed $1 \%$ (which does not even cover the costs of the fee system itself). Since environmental pollution is so serious, an effective fee would have to be set at such a high level that it would be impossible to pay. The same applies to all direct control methods. They cannot be enforced too aggressively or else the entire production system would collapse.

Given this situation, one might expect more action at the central level, but effective organization is impeded by systemic factors. The sector ministries at the state level are responsible for sector-level planning. Traditionally, these ministries have aimed at maximizing their physical output; pollution abatement has not been part of their mission. Even when it was realized that pollution could affect output, the incorporation of abatement efforts remained a task of secondary importance. Planning of investments for environmental purposes takes place only after the inputs necessary for production have been procured. These inflexible practices cannot integrate environmental goals in the planning of the economic sector ministries. 
The integration of these goals requires a different approach at the state level, including the establishment of independent environmental protection agencies. Unfortunately, attempts at coordination have not been successful so far. Although environmental protection agencies have been set up and their decisions are binding, the lack of integration of environmental targets in the sectoral planning process has remained a persistent problem. In view of the growing concern about the environment, this can no longer be explained by the priority given to production. The main difficulty seems to be the lack of coordination and communication between different government departments and environmental agencies.

Because of these difficulties, the means allotted to pollution abatement investments are inadequate for meeting legal emission standards, and little attention has been paid to the development of pollution control technologies. No such technology was imported, since this was too expensive, and its lack is felt especially in heavy industry, power plants, and energy transport; in many cases there is no control technology at all. [See Nentjes (1990) or Wilczynski (1990) for additional remarks on environmental policy.]

\section{DEVELOPMENTS IN THEORY AND PRACTICE}

Over the past decades environmental economics has developed an impressive body of knowledge. At its core lies a rich tradition in formulating ingenious approaches to the problem of distributing the external costs of production among the parties concerned. Here we have a variety of cases, ranging from the relatively simple case, where the choice will be between the extremes of imposing a Pigouvian tax or engaging in Coasian bargaining, to realistic cases in industrial areas requiring combinations of market elements and purely administrative standards, such as the so-called 'bubble-concept' (Crocker, 1966; Weitzman, 1974).

In the case of transfrontier pollution, the situation is even more complicated since links between specific polluting activities and specific types of damage are extremely difficult to establish. Moreover, promising solutions would often require structural adaptations in sectors such as energy and transport which are vital to each state. The situation basically requires new forms of bargaining but in a cooperative setting. An interesting example is the so-called $30 \% \mathrm{Club}$, an organization of states which committed themselves in Helsinki in 1985 to the reduction of $\mathrm{SO}_{2}$ emissions (from the level of 1980) by $30 \%$ by 1993 . Various forms of mutual assistance are being debated, including side-payments and other incentives.

Isolation of the communist countries of Eastern Europe was rather extreme. In fact, they engaged in foreign trade with countries outside the CMEA block only to obtain hard currency to buy those commodities that were not or could not be produced at home (Wolf, 1988). Because of the isolation of these countries, Western countries did not have many ways of retaliating against transfrontier pollution. Economic theory suggests that second-best policies, such as tariffs on 
the polluting goods, may have a desirable allocative effect. However, such policies are instrumental only if the polluted countries are in a position to affect prices and outputs of the polluting goods (Baumol and Oates, 1988).

Because traditional neo-classical instruments could not be applied, special forms of cooperation received attention in the relevant literature, partly inspired by the increased interest in Eastern Europe during the mid and late 1980s. Popular theoretical settings are differential game frameworks to characterize optimal control charges for cases of cooperatively (or, by contrast, noncooperatively) determined policies, including cases where countries would opt for generally non-efficient uniform emission reductions (see Van der Ploeg and de Zeeuw, 1990). Another example is Nentjes' (1988) supply and demand model for mutual international pollution reduction, which incorporated a tatonnement process. Such models showed that cooperation would pay off significantly.

Empirical studies appear to confirm these theoretical results. Mäler (1988), employing a game-theoretical framework, studied certain aspects of the transfrontier pollution problem using preliminary data on more than two dozen European countries, and found strong preliminary evidence that cooperation would considerably reduce overall pollution. Comparable results, also of a preliminary nature, were obtained by Löwgren (1990) in a study confined to the Baltic area.

Given the existence of substantial inter-country marginal cost differences, almost any form of institutionalized cooperation would involve a considerable overall cost advantage over isolated, national strategies. However, as an optimal policy would most likely require asymmetric emission reductions and hence asymmetrically distributed financial burdens, such an uneven distribution would probably generate opposition from those countries that would bear most of the cost of the new scheme.

To avoid an impasse under such circumstances, it seems useful to establish a system of inter-country transfers of a financial or technical nature. Some attention has been given to the description of properties which a fund for sharing the costs of the acid rain abatement policy in Europe should have. Obviously a successful 'sharing-fund' would have to incorporate a realistic incentive mechanism for each participant to avoid free riders (a point already noticed by Mäler, 1988). It is still an open problem which properties such a fund should have (Bergman et al. 1990). Without such a mechanism, however, the process most likely will not succeed let alone be optimal.

An interesting scheme based on this idea has been proposed by Klaassen and Jansen (1989). This scheme is based on the amount of money that the individual countries have pledged for their abatement programmes. These costs can be set off against the benefits, measured as a function of decreased depositions. Marginal costs per unit of prevented emission are determined via country-specific cost functions, and marginal benefits are calculated as functions of the corresponding reduction in deposition. As long as marginal benefits are larger than marginal costs, the country will be able to put more effort into abatement. Part of such abatement efforts will result in decreased depositions in the neighbouring 
countries, and in a neo-classical framework these countries would pay the costs. This would increase (marginal) benefits even further, and a country would now be able to further reduce emissions up to the point where the marginal costs of further emission reduction equal the marginal benefits. The results of computations by Klaassen and Jansen are given in Table 4 . They show that cooperative programmes for the reduction of acid rain-generating emissions can be beneficial to all participants. The technology discussed is essentially 'end-of-pipe'.

The second column in Table 4 gives the reduction of $\mathrm{SO}_{2}$ emissions as planned. If all countries pay for the benefits they receive through the other countries'

TABle 4. Results with Side Payments, $\mathrm{SO}_{2}$ Abatement Programme ${ }^{1}$

\begin{tabular}{|c|c|c|c|c|c|}
\hline Country & $\begin{array}{l}\text { Planned emission } \\
\text { reduction policies }\end{array}$ & $\begin{array}{l}\text { Reduction with } \\
\text { side payments }\end{array}$ & $\begin{array}{c}\text { Costs of } \\
\text { planned } \\
\text { abatement } \\
\text { policies } \\
\left(10^{6} \mathrm{DM}\right)\end{array}$ & $\begin{array}{l}\text { Costs with } \\
\text { side } \\
\text { payments } \\
\left(10^{6} \mathrm{DM}\right)\end{array}$ & $\begin{array}{l}\text { Net benefits } \\
\text { over presen } \\
\text { policies } \\
\left(10^{6} \mathrm{DM}\right)\end{array}$ \\
\hline $\begin{array}{l}\text { Country: } \\
\text { ALB }^{3}\end{array}$ & -100 & -100 & 0 & 0 & 0 \\
\hline AUS & 70 & 73 & 439 & 492 & 1148 \\
\hline BEL & 30 & 57 & 4 & 276 & 27 \\
\hline BUL & 30 & 41 & 627 & 772 & 67 \\
\hline CZE & 30 & 75 & 102 & 1486 & 223 \\
\hline DEN & 50 & 82 & 261 & 604 & 378 \\
\hline FIN & 50 & 59 & 257 & 423 & 627 \\
\hline FRA & 50 & 61 & 0 & 224 & -224 \\
\hline GDR & 30 & 79 & 798 & 2805 & -289 \\
\hline FRG & 65 & 75 & 2957 & 3758 & 2955 \\
\hline GRE & -174 & -174 & 0 & 0 & 0 \\
\hline HUN & 30 & 70 & 128 & 529 & -40 \\
\hline IRE & -18 & -18 & 0 & 0 & 0 \\
\hline ITA & 30 & 52 & 247 & 1091 & 696 \\
\hline LUX & 60 & 77 & 92 & 124 & 163 \\
\hline NET & 50 & 70 & 402 & 629 & 360 \\
\hline NOR & 50 & 50 & 200 & 200 & 1051 \\
\hline POL & 2 & 32 & 0 & 663 & -663 \\
\hline POR & -32 & -32 & 0 & 0 & 0 \\
\hline ROM & -55 & -55 & 0 & 0 & 0 \\
\hline ESP & -2 & -2 & 0 & 0 & 0 \\
\hline SWE & 65 & 65 & 477 & 477 & 2249 \\
\hline SWI & 50 & 50 & 58 & 58 & 200 \\
\hline TUR & -179 & -179 & 0 & 0 & 0 \\
\hline UK & 30 & 61 & 627 & 2359 & -594 \\
\hline USS & 30 & 59 & 4282 & 9318 & 1424 \\
\hline YUG & -158 & -144 & 0 & 145 & -145 \\
\hline Total & 18 & 42 & 11,958 & 26,433 & 9913 \\
\hline
\end{tabular}

${ }^{1} \mathrm{~A}$ negative sign in columns 2 and 3 indicates an increase in emissions. These increases are anticipated in countries that did not sign an international agreement or that initially had very low emissions.

${ }^{2}$ Percentage decline from 1980.

3 Countries are, respectively, Albania, Austria, Belgium, Bulgaria, Czechoslovakia, Denmark, Finland, France, GDR, FRG, Greece, Hungary, Ireland, Italy, Luxemburg, Netherlands, Norway, Poland, Portugal, Rumania, Spain, Sweden, Switzerland, Turkey, UK, USSR, and Yugoslavia.

Source: Klaassen and Jansen (1989). 
emission reduction plans, emissions can be further reduced, as given in the third column. The fourth column gives the costs of the planned abatement policies, while the fifth column gives the costs of programs with side payments. The last column gives net benefits (total benefits minus total costs). (For a discussion of the various intermediate outcomes required, refer to the original article.) The cost of the programme is seen to be around 12 billion D-Marks if planned policies are carried out without taking into account the effects on other countries. If side-payments are introduced to account for these effects, the cost of the programme appears to be more than 26 billion D-Marks.

Extensions of this type of work are now being developed which will link the existing model to an industrially based model with explicit representation of the use of energy. Within the expanded framework it will be possible to evaluate the effects of energy conservation techniques, fuel shifts, and renewable energy sources (Remmers et al., 1989). ${ }^{1}$

Despite these results, practical implementation may prove difficult. For example, Zylicz (1990) expressly warns that in Eastern Europe there are few opportunities for relatively inexpensive pollution reduction, since end-of-pipe technology generally is not efficient. In addition, even though average unit costs of reduction are often lower in these countries, the economic burden of any given percentage reduction programme is several times higher than in the West because of larger quantities to be removed relative to the level of overall economic activity.

\section{REALITIES}

Countries that do not participate in international trade generally lack incentives to improve economic productivity. In a mild form, this has been the situation of protected traditional industries in Western Europe, such as textiles, iron and steel.

Because of their isolation, it is not surprising that the Eastern European economies today have many aspects that are reminiscent of Western Europe during the 1940s and 1950s, such as a coal-based energy generation, a large amount of traditional industrial production relative to services, and an exceptionally high energy intensity. Environmental consequences are also reminiscent of the situation in the West European countries one or two generations ago (partly reflected in Tables $1-4$ ).

Now that this isolation is ending, one of the main aims in Eastern Europe is to catch up with the West as rapidly as possible. Unfortunately, there is no history of serious debate on the problems involved in a possible period of transition and

\footnotetext{
1 The potential of coordination has also been demonstrated using other models, such as RAINS (an integrated model for the control of acidification in Europe, developed at IIASA), the European Community's energy/environmental model EFOM-ENV (a multi-period dynamic linear optimization model), the Danish Brundtland Energy Scenario Model (a technical-economic model integrating long-term growth scenarios for energy consumption and focusing especially on the possibilities for acid rain reduction), and others.
} 
reconstruction. As a result there is a lack of both theoretical ideas and political consensus. There is agreement on the need for macro-economic stabilization, including a more realistic pricing system, privatization, and decentralization measures, and the means to create technical experts and financial systems. Opinions, however, differ about the rate at which these measures should be carried out. Advocates of 'crash' programmes, notably in Poland and the ex-GDR [see especially Kornai (1990) for a defence of a speedy transition] clash with advocates of more gradual change (Czechoslovakia).

The introduction of a market economy in Eastern Europe implies that the type of international environmental cooperation that was beginning to emerge-as discussed in Section 4-will have to be reconsidered. The reason for this is obvious: these forms of cooperation were geared to the central planning system in Eastern Europe. Given the demise of central planning, the East European enterprises must work under totally changed conditions, and we have to ask ourselves whether conditions for the type of schemes presented earlier still exist.

Schreiber (1990) gives the following classification of East European plants.

(i) Factories that do not meet minimal Western standards and are a clear hazard. In many cases these were built around the turn of the century and have never been modernized. An estimated $10 \%$ of all plants and factories falls within this category.

(ii) Factories that do not meet Western standards, but pose a less serious threat. This category includes an estimated $80 \%$ of plants. Because of this number, it is unrealistic to close these factories. They will have to be modernized and reconstructed. A cheaper, less effective, and more temporary solution will be to install end-of-pipe controls like scrubbers.

(iii) The remaining $10 \%$ more or less meet Western environmental and productivity standards.

The above list is probably too optimistic from an economic point of view. For example, according to Janke (1990), 75\% of the industrial base in East Germany may not be competitive. The experience of the Treuhand, the German organization charged with the sale of some 8000 former GDR-state enterprises, is in line with that observation. So far about 1000 of them have been sold, nearly all of them small enterprises such as farms, bakeries, and restaurants. The larger industrial enterprises generally appear to have a slim chance of being sold, and most will likely be closed down. This implies that forms of cooperation of the type discussed in Section 4 loose their relevance.

The experience in East Germany, which is now known, presents an interesting showcase of the multitude of interrelated problems to be expected in the near future. Suhr (1990) lists a number of recent studies with cost estimates of the restructuring effort if the former GDR area is to be brought up to the West German level in 10 years. Outlays in the categories of environmental clean-up, housing and city restructuring, electricity and city heating, energy conservation, agricultural sanitation, railways, roads, post and telecommunication, and education alone total more than 1850 billion D-Marks of 1990 . Costs of re-industrialization of the 
area of the former GDR are estimated at about 2700 billion D-Marks of 1990 (Siebert, 1991). The situation for the other former CMEA countries in Eastern Europe is often even worse and will therefore require special efforts by other parties. We shall return to this prospect in the next section.

Regarding the united Germany, it has now become clear that the catching-up strategy for East Germany will be strongly modelled on the West German experience. For example, new (high speed) turnpikes are being planned with no serious consideration about the development of transport alternatives to the private car such as the so-called 'Huckepack methods'. Opportunities to proceed differently, and achieve more desirable environmental outcomes than West Germany may well be lost. [See Folmer and Howe (1991) about the formidable environmental problems confronting the Single European Market of the 'Twelve'.)

\section{PRESENT EC POLICY}

Many strategies were designed in the 1980 s to enhance European competitiveness in the global market. The creation of the internal European market and the portrayal of the Community as a single unit played a central role in these strategies. Supply side arguments provided the basis for the Community's industrial policy. The aim was to create conditions favourable for the development of industrial markets in a competitive social system. European Community policy has since focused on the development of special programmes designed to enhance European strength in areas such as high-technology production, energy, and environmental protection. Programmes like Comett and Erasmus aim at creating a strong research basis. Another strategic investment is the TGV (Train à Grande Vitesse), as an alternative to air and automobile transport. Other programmes are intended to promote internal cooperation, a unified labour market, a balanced mix of primary fuels, a supportive fiscal policy, and extensive contacts among universities and enterprises. These activities contrast with the policies of the 1970 s and early 1980 s, when the emphasis was on direct support for ailing sectors such as shipbuilding, automobiles, and computers.

The European aid and support programme for less-developed areas in the EC also promotes emphasis on infrastructure and know-how, combined with general reductions in subsidies. The Community's programme for these areas has recently been greatly expanded. In the fiscal year 1992 aid will amount to 13.5 billion Ecu, rising in 1993 to 14 billion Ecu. Germany, for instance, will receive about 3 billion Ecu per year from the Community for the restoration of the former GDR.

The same policy has basically been adopted for Eastern Europe. According to the President of the European Committee, a similar programme for the formerly centrally planned countries, including the former GDR, would burden the European budget by an additional 14 billion Ecu annually. If this effort was to be sustained for 10 years, this would mean an amount of 140 billion Ecu.

The adoption of the same policy for Eastern Europe as for the underdeveloped areas of the EC shows that a sound theoretical basis for East European 
reconstruction is lacking. Of course, a reliable network of roads and railway systems, fiscal and financial incentives, the establishment of joint production facilities, and secondary and higher education programmes are indispensable. However, there is no guarantee that transition to a market economy will lead to an improvement of the situation in the foreseeable future which is the expressed aim. In this context, Porter's views (1990) about international economic competitiveness are illuminating. In his frame of reference, the West German economy prospers because all of the four essential factors identified by him are present: a good infrastructure, a highly critical and demanding domestic market, an extensive network of interconnected producers, including an excellent research tradition, and an economic order which has remained stable and basically unchanged during the last four decades. German restructuring efforts so far can also be interpreted in this framework. Although Germany is pursuing all four objectives, the emphasis is on the first. Inside the former GDR, the second, the third, and fourth factors are practically non-existent.

If we accept Porter's framework, the other East European countries have only a remote chance of catching up with the West. All of them combined receive only a fraction of the support given to the former GDR. Their advantages are of a classical nature, such as low labour costs and favourable geographic locations. In the absence of Porter's factors, however, the transition will be slow and painful. European aid programmes aim at strengthening only the first factor. One factor the existing aid programmes can surely not provide is the stimulating competitive home market. The demand for Western goods seems insatiable for the foreseeable future and is forcing Eastern producers out of the market. [For documentation concerning the ex-GDR, see Furet and Holzapfel (1990).]

To date, Western assistance (including efforts of the IMF, the World Bank, the newly created EBRD, and bilateral agreements) has proven inadequate in scope and consistency. Even in the German case, these efforts will probably not be sufficient to prevent large-scale migrations. During the last days of the GDR, 2000 persons migrated to the West every day. At present many thousands are still leaving East Germany for better opportunities in the West. The state of Saxony, for example, still loses 10,000 people each month.

\section{CONCLUSION}

In this paper we have stressed the fact that the new situation in Eastern Europe is a combination of serious environmental problems and economic problems. This, as we have indicated, requires a linkage of environmental policy programmes to economic revival programmes. The Germans have already done a great deal in this respect. Many highly polluting factories have been closed down. Economically this made sense because the products made in these factories were no longer in demand. Politically it was possible since a social security system is being constructed.

Other East European countries have also taken drastic steps. Poland, for example, recently closed down 100 of its most polluting enterprises. This made 
economic sense because these factories did not add much to national product. Nevertheless, Germany can afford to do much more while countries like Poland have far less room for manoeuvre. A German-type 'cloning' process obviously cannot be applied, and this means that other initiatives need to be introduced.

Yet present EC policy is simply a continuation of the old policy which is practical only in societies that are capable of automatic adjustments. Like Hare (1990) and Kaser (1990), we concur that traditional EC economic development policy is not relevant to Eastern Europe. An indication of what may be needed is given by the recent instructions for a change of policy of the German 'Treuhand'. In the light of recent developments, purely economic factors (such as economic viability) have given way to a politically motivated focus on other factors, mainly employment guarantees. However, such efforts can, at best, only alleviate the problems. There is no alternative but for the EC to quickly develop an active policy towards its Eastern neighbours. Creative and unorthodox approaches are urgently required.

For example, Schreiber (1990) calls attention to a ' $50 \%$ solution'. This solution is based on the idea that an optimal solution would require the installation of new technologies. Because of the probable infeasibility of this, however, alternatives should be investigated. This in turn requires a definition of objectives: what exactly is it that we want to achieve? If our objective is simply a rapid reduction of environmental pollution, we would have to aim at a kind of compromise between a more or less immediate reduction of air pollution and long-term competitiveness. This would mean the implementation of 'second-best' solutions: resorting to a high incidence of filters, scrubbers, and other 'end-of-pipe' technology, combined with special efforts to keep the enterprises working that have some chance of survival. ${ }^{2}$ This would buy time to develop other strategies. The present situation is, in a sense, the outcome of a Coasian type of 'bargaining' where the 'sinner' (Eastern Europe) has won the access rights to the environment (and the money of the Western market economies).

If this fails, Western Europe must face the prospect of rapidly increasing pressure on its markets, above all the labour markets. According to certain polls, millions of people would leave their homeland for a better future. Rough cost-benefit calculations can be made regarding the costs of resettlement, housing, schooling, the creation of job opportunities, etc. At a conservative estimate of $\$ 200,000$ per person, for 10 million interested people this could cost $\$ 2000$ billion over the next decade, roughly the estimated cost of East German reconstruction. Whatever Europe decides to do, it will be faced with costs of this magnitude.

\footnotetext{
${ }^{2}$ Hughes (1990) has a different opinion and argues that the costs of reducing environmental pollution in Eastern Europe are being exaggerated. Apart from a number of well-known disaster 'pockets', he claims that the general exposure level to major pollutants should not be high by comparison with the OECD countries. Even without specific environmental policies, economic reforms, combined with energy conservation through more realistic pricing, may be expected to reduce emissions roughly by $50 \%$. What remains is the aftermath of past industrial activity which has to be treated over an extended period.
} 


\section{ACKNOWLEDGEMENTS}

The author is indebted to Faye Duchin, Herman Cesar, Andries Nentjes, and Thomas Zylicz for discussions and comments on an earlier version.

\section{REFERENCES}

Baumol, W. J. and Oates, W. (1988). The Theory of Environmental Policy. Cambridge University Press, Cambridge.

Bergman, L., Cesar, H. and Klaassen, G. (1990). 'A Scheme for Sharing the Costs of Reducing Sulphur Emissions in Europe'. Working Paper, 90-005, IIASA, Laxenburg.

BERLINER, J. S. (1988). Soviet Industry: From Stalin to Gorbachev. Edward Elgar, Aldershot.

Bojcun, M. (1991). 'The Legacy of Chernobyl', New Scientist, 20, 30-5.

CesAR, H. S. J. (1990). 'Environmental Issues in Eastern Europe: Description and Annotated Bibliography'. Mimeo, World Bank.

Chander, W. V. (1990). 'Industrial Energy Perspective: a Policy Perspective', UNEP Industry and Environment, Jan-Mar, 9-12.

CROCKER, T. D. (1966). 'Structuring of Atmospheric Pollution Control Systems', in H. Wolozin (ed.), The Economics of Air Pollution. Norton, New York.

Duchin, F., LANGe, G.-M. and Thonstad, K. (1991). 'Strategies for Environmentally Sound Economic Development'. Progress Report No. 7, Institute for Economic Analysis, New York, NY.

Energy Economist, Various authors (July 1990), 105, 9-13.

Famielec, J. and Gorka, K. (1991). 'Economic Losses Due to Environmental Pollution in Poland and the Cracow Region'. Paper presented at the second meeting of the European Association of Environmental and Resource Economists, Stockholm.

Folmer, H. and Howe, C. W. (1991). 'Environmental problems and Policy in the Single European Market', Environmental and Resource Economics, 1.

FrenCH, H. F. (1988). 'Industrial Wasteland', World-Watch, Nov-Dec, 30.

- (1990). 'Green Revolutions: Environmental Reconstruction in Eastern Europe and the Soviet Union'. Worldwatch Paper 99.

Furet, M. and HolzAPFEL J. (1990). 'Die Eingliederung der ostdeutschen Landwir̂tschaft in die EG', Vorgänge, 6.

Hare, P. (1990). 'From Central Planning to Market Economy: Some Microeconomic Issues', The Economic Journal, 100, 581-95.

Hughes, G. (1990). 'Are the Costs of Cleaning up Eastern Europe Exaggerated? Economic Reform and the Environment'. CPER Discussion Paper 482, London.

IMF, The World Bank, OECD, AND EBRD (1991). A Study of the Soviet Economy. Part V, Ch. V.1, Paris.

JANKE, A. (1990), cited in K. von Dohnanyi, 'Das Deutsche Wagnis, die Risiken der deutschedeutschen Vereinigung (IV), Der Spiegel, 42.

Kaser, M. (1990). 'The Technology of Decontrol: Some Macroeconomic Issues', The Economic Journal, 100, 596-615.

KlaAssen, G. and Jansen, H. M. A. (1989). 'Economic Principles for Allocating the Costs of Reducing Sulfur Emissions in Europe'. Institute for Environmental Studies. Free University, Amsterdam.

KornaI, J. (1990). The Road to a Free Economy. W. W. Norton, New York.

Löwgren, M. (1990). 'Transfrontier Pollution: Cost-Effective Abatement Strategies in Northern Europe'. Department of Water and Environmental Studies, University of Linköping.

MÄLER, K. G. (1988). 'Transboundary Pollution and International Conflicts'. Paper presented at the International Conference on Environmental Stress and Security, Stockholm.

MazurSKi, K. R. (1990). 'Industrial Pollution: The Threat to Polish Forests', Ambio, 19, 2, 70-4.

NentJes, A. (1988). 'Public Decision Making in International Pollution'. Paper presented at the International Institute of Finance 44th Congress, Istanbul.

- (1990). 'Perestroika in USSR environmental policy'. Paper presented at the first meeting of European Association of Environmental and Resource Economists, Venice.

PORTER, M. E. (1990). The Competitive Advantage of Nations. Macmillan, London. 
Remmers, J., Morgenstern, T., Schons, G., HaAsis, H.-D. and Rentz, O. (1989). 'Integration of Air Pollution Control Technologies in Linear Energy-Environmental Models', European Journal of Operations Research, 47, 306-16.

Rich, V. (1991). 'An Ill Wind from Chernobyl', New Scientist, 20, 26-8.

Russell, J. (1990). Environmental Issues in Eastern Europe: Setting an Agenda. World Conservation Union, London.

SCHREIBER, H. (1990). 'The Continent's Conundrum', The Environmental Forum, Sept-Oct.

SIEBERT, H. (1991). 'The Integration of Germany: Real Economic Adjustment', European Economic Review, 35, 591-602.

SPETTER, H. (1990). 'Bulgaria Under the Grave Impact of Chernobyl', Environmental Policy Review, $4,51-4$.

SuHR, H. (1990). Was kostet uns die ehemalige DDR. Eichborn, Frankfurt am Main.

TremL, V. G. (1982). Alcohol in the USSR; A Statistical Study. Duke Press Policy Studies, Durham, NC.

Van Der Ploeg, F., and de Zeeuw, A. J. (1990). 'International Aspects of Pollution Control'. Center for Economic Research, Tilburg University.

Wertzman, M. L. (1974). 'Prices Versus Quantities', The Review of Economic Studies, XLI, 477-91.

WILCZYNSKI, P. (1990). 'Environmental Management in Centrally-Planned Non-Market Economies of Eastern Europe'. Environment Working Paper no. 35, The World Bank, Environment Department, Sector Policy and Research Staff.

WNUK-LIPINSKI, E. and ILLSLEY, R. eds (1990). 'International Comparative Analysis: Main Findings and Conclusions', Social Sciences and Medicine, 31, 879-89.

Wolf, T. A. (1988). Foreign Trade in the Centrally Planned Economy. Harwood, Chur.

Wolfson, Z. (1990). 'Chernobyl, for Official Use Only; A Book Preview', Environmental Policy Review, 4, No. 2, 37-41.

ZyLICZ, T. (1990). 'Environmental Policies for Former Centrally Planned Economies: a Polish Perspective'. Paper presented at the conference of the European Association of Environmental and Resource Economists, Venice. 